\title{
PENGGUNAAN GRAMATIKA DALAM WACANA POLITIK: STUDI REPRESENTASI BAHASA SEBAGAI SISTEM MAKNA SOSIAL DAN POLITIK
}

\author{
oleh Anang Santoso \\ FS Universitas Negeri Malang
}

\begin{abstract}
The grammar of the Indonesian language is greatly made use of in political discourse and especially after the era of the Old Order. Via grammatical forms, the political elite fights for its power and ideology, both explicitly and implicitly, causing an unbalanced political communication. A research study this article is about was conducted to (1) describe and interpret the utilization of grammaticality in political discourse and (2) clarify why certain grammatical forms are paid special attention while others are not.

The study applied a critical qualitative approach with a "critical discourse analysis" design from Fairclough (1989: 1995). In this perspective, no text produced by the political elite is neutral from political interest. Discourse is a social construction and results from social-historical and political conditions. There is no discourse which is a social vacuum. Discourse is a social creation reflecting the interests of certain social groups.

The research results indicate that (1) each group of the Indonesian political elite uses transitivity with material meaning, agent nominalization, the passive voice, and the negative form to show its power and hide its ideological position, (2) each assumes the role of information provider, shows its authority in the presence of the other groups and the Indonesian society, and asserts its power by choosing to use the personal pronouns we and $I$, (3) it makes considerable use of modality expressing authority, and (4) there are institutional and cultural processes explaining why certain grammatical forms are paid special attention while others are not.
\end{abstract}

Keywords: grammaticality, political discourse,

\section{A. PENDAHULUAN}

Bahasa politik selalu ditata sedemikian rupa yang di dalamnya penuh dengan muatan kuasa dan ideologi yang tersembunyi di dalam struktur-struktur lingual (Fowler, 1986; Birch, 1996). Struktur lingual itu dipergunakan untuk (1) mensistematisasikan, mentransformasikan, dan mengaburkan realitas, (2) mengatur ide dan perilaku orang lain, (3) mengklasifikasikan dan menggolongkan masyarakat, peristiwa, serta objek-objek untuk menegaskan status institusional dan personal. Pilihan bahasa dibuat menurut seperangkat kendala politis, sosial, kultural, dan ideologis. Dengan keberadaan kendala-kendala itu, menurut Birch (1996:79), masyarakat dapat dimanipulasikan dan dinilai peran serta status bawahan/atasan melalui sistem strategi kekuasaan (aturan dan subordinasi), solidaritas (kohesi dan antagonisme) yang semuanya merupakan bagian integral dari sistem-sistem penguasaan bahasa dan masyarakat.

Piranti-piranti lingual, termasuk di dalamnya aspak gramatika, menjadi "pintu 
gerbang" kajian linguistik terhadap wacana politik. Mengikuti pandangan Fairclough (1989), dalam piranti lingual terkandung tiga hal, yakni (1) "pengkodean realitas" yang disebut dengan nilai pengalaman, (2) "pengkodean hubungan antarmanusia" yang disebut nilai relasi, dan (3) "pengkodean status sosial penghasil teks" yang disebut nilai ekspresif. Diduga persoalan penggunaan gramatika oleh elite politik menjadi salah satu sumber kesemrawutan kehidupan sosial politik Indonesia. Menurut Fairclough (1989) nilai pengalaman gramatika tampak pada (1) ketransitifan, (2) nominalisasi, (3) kalimat aktif-pasif, dan (4) kalimat positif-negatif; nilai relasi gramatika tampak pada (1) modus kalimat deklaratif-interogatif-imperatif, (2) modalitas relasional, dan (3) pronomina persona; nilai ekspresif gramatika tampak pada penggunaan modalitas ekspresif.

Penelitian ini bertujuan (1) memerikan dan menafsirkan pendayagunaan "nilai pengalaman" gramatika dalam wacana politik, (2) memerikan dan menafsirkan pendayagunaan "nilai relasi" gramatika dalam wacana politik, (3) memerikan dan menafsirkan pendayagunaan "nilai ekspresif" gramatika dalam wacana politik, dan (4) menjelaskan mengapa bentuk gramatika tertentu dipilih dan diistimewakan, serta mengapa bentuk-bentuk gramatika lainnya tidak dipilih dan tidak diistimewakan oleh elite politik dalam wacana politik.

Bahasa politik dalam penelitian ini merujuk pada pandangan Mueller (1980), Cross (1986), Bosmajian (1986), dan Safire (1986), yakni karakteristik bahasa yang dihasilkan oleh para politisi dalam menjalankan aktivitas politiknya. Dalam konteks proses-proses sosial, politik, dan kultural, bahasa digunakan untuk mengendalikan masyarakat melalui pengontrolan makna. Mengaji bahasa politik haruslah ditempatkan dalam konteks komunikasi politik.

Birch (1996:69) mengemukakan enam asumsi penting terkait dengan komunikasi. Pertama, komunikasi selalu politik sebelum bentuk lingualnya. Kendala-kendala politik, sosial, kultural, dan ideologi akan menentukan pilihan bahasanya. Dalam proses memilih itu terdapat bentuk lingual yang diistimewakan, dan ada bentuk yang tidak diistimewakan. Kedua, komunikasi selalu motivated, interested, dan situated. Bentuk-bentuk lingual yang dipilih digunakan untuk mengendalikan dan mengarahkan orang lain, membuat makna tentang realitas, dan mengelompokkan sesuatu dalam realitas. Ketiga, komunikasi selalu strategi. Tindak komunikasi selalu berkaitan dengan "siasat" untuk mencapai tujuan-tujuan tertentu. Tidak ada tindak komunikasi yang tidak berupa strategi. Keempat, komunikasi selalu terjadi dalam perjumpaan dan interaksi. Tindak komunikasi selalu melibatkan orang lain. Dalam komunikasi akan terjadi pertukaran makna antarpartisipan. Kelima, komunikasi selalu berkaitan dengan nilai. Bentuk-bentuk lingual yang dipilih akan berkaitan dengan nilai-nilai yang dikembangkan sepanjang waktu. Keenam, komunikasi selalu bersifat bergantung (contingent). Tindak komunikasi selalu bergantung pada cara-cara institusi, kelompok, dan individu memberikan nilai kepada makna-makna tertentu. Makna selalu berkembang sepanjang waktu. Makna bukanlah sesuatu yang alamiah, tetapi dibangun dalam proses sosial dan politik.

Dalam politik, komunikasi yang dihasilkan adalah komunikasi yang terkendala (constrained communication), yakni komunikasi yang timpang kekuasaan antara penghasil teks dan konsumen teks. Di satu sisi elite politik berusaha mendayagunakan bahasa untuk kepentingan politiknya, di sisi lain masyarakat sering berbuat keliru atau tidak tepat dalam menafsirkan bahasa politik yang dihasilkan oleh elite politik itu.

Untuk menggali kuasa dan ideologi digunakan pendekatan kritis dalam kajian bahasa. Linguistik kritis merupakan kajian ilmu bahasa yang bertujuan mengungkap relasirelasi kuasa tersembunyi (hidden power) dengan proses-proses ideologis yang muncul dalam teks-teks lisan atau tulisan (Crystal, 1991:90). Analisis linguistik belaka diyakini tidak dapat mengungkapkan signifikansi kritis. 
Menurut Fowler (1986:6) hanya analisis kritis yang merealisasikan "teks sebagai modus wacana" serta memperlakukan teks sebagai wacana yang akan dapat melakukannya.

Dalam hubungannya dengan makna struktur lingual, sesuatu yang amat fundamental dalam pandangan Fowler (1986) dan Fairclough (1989) adalah terdapatnya fungsi hubungan antara konstruksi tekstual dengan kondisi-kondisi sosial, institusional, dan ideologis dalam proses-proses produksi serta resepsinya. Pandangan tersebut memperkuat pandangan van Dijk (1985:7) yang menyebutkan bahwa fitur-fitur wacana hanyalah menjadi "gejala" (symptoms) dari persoalan-persoalan yang lebih besar, seperti ketidakadilan, perbedaan kelas, gender, rasisme, kekuasaan, dan dominasi yang melibatkan lebih dari hanya sekedar teks dan tuturan. Struktur-struktur lingual digunakan untuk mensistematisasikan dan mentransformasikan realitas. Oleh karena itu, dimensi kesejarahan, struktur sosial, dan ideologi adalah sumber utama pengetahuan dan hipotesis dalam kerangka kerja kritisisme linguistik (Fowler, 1986:8). Linguistik kritis amat relevan digunakan untuk menganalisis fenomena komunikasi yang penuh dengan kesenjangan, yakni adanya ketidaksetaraan relasi antarpartisipan, seperti komunikasi dalam politik, relasi antara atasan-bawahan, komunikasi dalam wacana media massa, serta relasi antara laki-laki dan perempuan dalam politik gender.

Wacana dalam pandangan kritis, mengikuti pandangan (Fairclough, 1995:135), harus dilihat secara simultan sebagai (1) teksteks bahasa, (2) praksis kewacanaan, dan (3) praksis sosiokultural. Menganalisis wacana secara kritis hakikatnya adalah menganalisis tiga dimensi wacana secara integral. Pertama, analisis teks bahasa. Dalam pandangan kritis, teks dibangun dari sejumlah piranti linguistik yang di dalamnya tersembunyi ideologi dan kekuasaan. Dalam penerapannya, AWK banyak memanfaatkan piranti linguistik yang disarankan dalam linguistik fungsionalsistemik Halliday $(1985 ; 1994)$ dan linguistik kritis Fowler (1986) untuk memerikan (to describe) kepemilikan struktur linguistik dalam teks bahasa. Kedua, analisis praksis wacana. Praksis wacana berkaitan dengan produksi dan interpretasi proses-proses diskursif. Analisis tahap kedua AWK ini berupa tahap menafsirkan (to interpret) relasi antara produksi dan interpretasi proses-proses diskursif itu. Ketiga, analisis praksis sosiokultural. Analisis tahap ketiga AWK ini berupa tahap menjelaskan (to explain) relasi fitur-fitur tekstual yang heterogen beserta kompleksitas proses wacana dengan proses perubahan sosiokultural, baik perubahan masyarakat, institusional, dan kultural. Menurut Fairclough (1989:163) tujuan eksplanasi ialah "memotret" wacana sebagai bagian proses sosial, sebagai praksis sosial, yang menunjukkan bagaimana wacana itu ditentukan oleh struktur sosial dan reproduktif apa saja yang mempengaruhi wacana yang secara kumulatif memakai, menopang, atau mengubah struktur-struktur itu.

Teori ketransitifan ini bersumber dari fungsi representasi bahasa, yakni fungsi bahasa yang bertugas (i) menyandikan (encode) pengalaman tentang dunia, dan (2) membawa gambaran tentang realitas. Dalam pandangan Halliday (1985:101) kepemilikan fundamental bahasa memungkinkan manusia itu membangun gambaran mental realitas dan membuat makna dari pengalaman tentang apa yang terjadi di sekitar dan di dalamnya. Teori ketransitifan dipergunakan untuk menjawab tiga persoalan pokok yang dilontarkan Fairclough (1989), yakni (i) tipe-tipe proses dan partisipan yang dominan, (ii) penampakan agen, dan (iii) penampakan proses.

Nominalisasi merujuk kepada proses pembentukan nomina dari beberapa kelas kata lainnya (Crystal, 1991:233; Richards, Platt, \& Platt, 1992:246). Dalam kajiannya tentang sintaksis bahasa Indonesia, Samsuri (1985:458 - 466) memaparkan adanya lima jenis nominalisasi dalam kalimat bahasa Indonesia, yakni (1) nominalisasi "bahwa", (2) nominalisasi minus "yang", (3) nominalisasi minus N, (4) nominalisasi rampatan, dan (5) nominalisasi "-nya". 
Proses-proses tindakan dapat muncul dalam kalimat aktif maupun pasif. Aktif dan pasif adalah persoalan voice, yakni bagaimana cara sebuah bahasa mengekspresikan hubungan antara frasa verba dan frasa nomina, serta pelbagai hal yang diasosiasikan dengan hubungan itu (Richards, Platt, \& Platt, 1992:401). Dua buah kalimat mungkin saja berbeda dalam voice-nya meskipun memiliki makna dasar yang sama. Dalam praktiknya, sebuah kalimat mungkin lebih sesuai atau lebih pantas dibandingkan dengan kalimat yang lain untuk situasi tertentu. Pilihan aktif-pasif ini berdampak pada kehadiran agen. Kalimat pasif yang dipilih, misalnya, sering menampilkan agen, dan sebaliknya sering meniadakan agen. Menurut Fairclough (1989:125) kalimat pasif tanpa agen membiarkan kausalitas dan kekaburan atau ketidakjelasan agen. Dalam banyak kasus, ketidakhadiran agen digunakan untuk menyembunyikan pelaku.

Pada umumnya nilai pengalaman diekspresikan dalam kalimat positif. Pada kasus tertentu, nilai pengalaman diekspresikan dalam kalimat negatif. Fairclough (1989:125) berpendapat bahwa negasi secara jelas memiliki nilai pengalaman sebagai cara dasar yang dimiliki manusia dalam membedakan apa yang bukan kasus dengan yang memang benarbenar kasus. Bentuk negasi menjalankan tiga fungsi: (1) negatif yang sesungguhnya, (2) negatif yang manipulatif, dan (3) negatif yang ideologis. Bentuk negatif berfungsi ideologis ketika bentuk ekspresi "nilai pengalaman" itu berfungsi melayani kekuasaan. Pertanyaan penting yang dimunculkan adalah "apa motivasi penulis atau pembicara menggunakan asersi negatif jika ia dapat mengungkapkan persoalan yang sama dalam asersi positif".

Modus kalimat adalah cara bagaimana kalimat itu diekspresikan kepada mitra bicara. Terdapat tiga cara, yakni (1) deklaratif, (2) pertanyaan gramatis, dan (3) imperatif. Tiga modus tersebut menempatkan subjek secara berbeda. Penempatan ini mengakibatkan ketidaksimetrisan sistematis. Fairclough (1989:126) berpendapat bahwa ketidaksimetrisan sistematis dalam pembagian modus antarpartisipan menjadi penunjuk dari hubungan partisipan. Bertanya, misalnya, pada umumnya berkaitan dengan "posisi kekuasaan". Bertanya dapat menjadi "tindakan" atau "informasi", dan dapat juga sebagai pemberi informasi. Deklaratif selain berarti pemberian informasi dapat juga berarti perintah. Bertanya selain berarti permintaan informasi juga dapat bernilai perintah.

Modalitas mengandung nilai relasional apabila modal itu digunakan terkait dengan autoritas satu partisipan dalam hubungan dengan partisipan lainnya. Dalam bahasa Indonesia, kajian yang mendalam tentang modalitas dilaksanakan oleh Alwi (1991). Hasilnya menunjukkan bahwa terdapat empat golongan besar modalitas: (1) intensional, (2) epistemik, (3) deontik, dan (4) dinamik. Modalitas intensional berkaitan dengan fungsi instrumental bahasa. Modalitas intensional dapat menyatakan 'keinginan', 'ajakan', 'pembiaran', dan 'permintaan'. Modalitas epistemik merupakan penilaian penutur terhadap kemungkinan dan keperluan bahwa sesuatu itu demikian atau tidak demikian (Alwi, 1991:90). Modalitas epistemik dapat mengekspresikan 'kemungkinan', 'keteramalan', 'keharusan', dan 'kepastian'. Modalitas deontik ini mengandung makna 'perintah', 'izin', dan 'larangan'. Modalitas dinamik mempersoalkan sikap pembicara terhadap aktualisasi peristiwa yang ditentukan oleh keadaan yang lebih bersifat empiris. Dalam modalitas dinamik terkandung makna 'mampu' atau 'sanggup'.

Pilihan pronomina persona berkenaan dengan bagaimana pembicara menghadirkan dirinya di hadapan mitra bicaranya. Pronomina persona adalah seperangkat pronomina yang merepresentasikan kategori gramatikal dari persona. Penggunaan pronomina persona dapat menunjukkan hubungan kekuasaan dan solidaritas. Penggunaan kata "Bapak" untuk menggantikan persona pertama mengandung arti bahwa orang pertama memiliki kedudukan yang lebih tinggi daripada mitra tuturnya itu. Untuk menunjukkan solidaritas setiap bahasa mempunyai pelbagai alat dan kata tertentu pula. 
Modalitas menjadi ekspresif jika modalitas adalah persoalan autoritas penbicara atau penulis yang berkenaan dengan kebenaran atau kemungkinan representasi realitas. Ditegaskan oleh Fairclough (1989:129) bahwa modalitas bukan hanya persoalan verba bantu modal. Pilihan terhadap verba bantu tertentu akan menampilkan gambaran yang berbeda tentang realitas. Bentuk-bentuk modalitas yang dipilih memiliki signifikansi ideologis tertentu.

\section{B. METODE PENELITIAN}

Penelitian ini termasuk penelitian kualitatif-kritis yang mendeskripsikan, menginterpretasikan, dan menjelaskan ideologi dalam bahasa politik (simak Fairclough, 1989, 1995). Penelitian ini menggunakan desain analisis wacana kritis yang memandang fenomena wacana dari tiga dimensi, yakni teksbahasa, praksis kewacanaan, dan praksis sosiokultural. Data gramatika meliputi (a) ketransitifan, (b) nominalisasi, (c) kalimat pasif, (d) kalimat negatif, (e) modus kalimat, (f) modalitas, dan $(\mathrm{g})$ pronomina persona dalam teks-teks (lisan dan tulisan) yang dihasilkan oleh elite politik. Pengumpulan data dilakukan dengan teknik perekaman dan studi dokumentasi terhadap teks yang sedang/sudah dihasilkan elite politik disertai pemahaman arti secara mendalam dan pemerian mendalam (Geertz, 1991). Dalam praktiknya, studi dokumentasi ini dilaksanakan oleh peneliti dengan critical \& creative reading serta reading between \& beyond the line seluruh teks.

\section{HASILDAN PEMBAHASAN \\ a. Nilai Pengalaman Gramatika dalam Wacana Politik}

Pilihan Ketransitifan. Analisis terhadap teks politik yang dihasilkan oleh 26 elite politik diperoleh informasi bahwa klausa material mendominasi keseluruhan proses yang digunakan. Hal itu menunjukkan bahwa proses "material" atau proses "tindakan" dalam klausa begitu menonjol didayagunakan dalam wacana politik bahasa Indonesia pada era pasca-Orde Baru. Sebagai gambaran awal, dari 26 ujaran elite politik yang dianalisis, dapat dikemukakan empat hal penting sebagai berikut. Pertama, sebagian besar teks politik, yakni teks yang dihasilkan oleh 23 elite politik, begitu didominasi oleh proses material. Kedua, teks politik dari 2 elite politik didominasi proses relasional atau proses atribusi. Ketiga, 1 teks politik mendayagunakan dua proses yang sama-sama dominan, yakni proses material dan mental, secara seimbang. Keempat, teks politik didominasi oleh proses mental atau proses merasakan secara dominan.

Belum seluruh ujaran elite politik dianalisis, baik dari segi penghasil wacana maupun jenis wacananya. Namun, dalam pandangan peneliti, kecenderungan adanya pendayagunaan klausa proses material atau tindakan oleh para elite politik Indonesia dapat dipertanggungjawabkan secara metodologis. Oleh karena itu, jika elite politik Indonesia lebih banyak menonjolkan aspek-aspek yang berkaitan dengan "perbuatan", "kejadian", dan "perilaku", hasil analisis sistem ketransifan di atas dapat memberikan jawaban awal tentang kecenderungan-kecenderungan dalam budaya politik Indonesia yang lebih mengedepankan perilaku-perilaku yang mengandalkan kekuatan fisik daripada kekuatan otak atau nalar.

Pilihan Nominalisasi. Nominalisasi yang digunakan dalam wacana politik meliputi nominalisasi yang menduduki partisipan, proses, dan partisipan. Nominalisasi yang menduduki partisipan mendominasi bahasa elite politik. Nominalisasi yang menduduki partisipan dapat digolongkan menjadi dua kelompok, yakni (1) nominalisasi yang menduduki agen, dan (2) nominalisasi yang menduduki goal dalam klausa. Nominalisasi yang menduduki partisipan, baik agen maupun goal banyak muncul dalam teks-teks politik yang dihasilkan oleh sejumlah elite politik Indonesia. Nominalisasi agen ini muncul dengan sejumlah bentuk, antara lain seperti "nominalisasi 'N+yang",, "nominalisasi "yang"," "nominalisasi "tanya", dan "nominalisasi "tanya+yang", Beberapa nominalisasi yang menduduki agen klausa dapat diperhatikan pada contoh (1) berikut. 
(1): [...] Saya kira kalau dibandingkan, jumlah rakyat yang mendukung digelar SI jauh lebih banyak. Sebab, misi rakyat yang ingin tetap melaksanakan SI ing in menyelamatkan negara dan bangsa.

Dalam kutipan (1) terdapat pendayagunaan nominalisasi pada konstruksi misi rakyat yang ingin tetap melaksanakan SI yang menduduki partisipan. Ditinjau dari susunan fungtornya, klausa kedua itu disusun dengan pola "agen+proses+goal" dengan nominalisasi sebagai pengisi bagian klausa yang menduduki agen itu. Jika dikembalikan kepada ide dasar Halliday bahwa pemolaan klausa adalah sebuah model variabel dari pengalaman manusia", pilihan nominalisasi agen dalam susunan "agen+proses+goal" itu merupakan model variabel bagaimana elite politik Indonesia memandang realitas, yakni masalah "pelaksanaan SI yang masih pro dan kontra itu". Dalam kasus itu, penghasil teks memandang bahwa misi ingin menyelamatkan negara dan bangsa sebagai bagian yang menduduki "proses" lebih penting daripada misi rakyat yang ingin tetap melaksanakan SI sebagai bagian yang menduduki "partisipan" meskipun dalam kenyataannya pelaksanaan SI adalah pintu gerbang untuk menyelamatkan negara dan bangsa. Dalam teori fungsional, proses lebih penting daripada partisipan atau "proses" lebih penting daripada "sesuatu". Dengan demikian, terdapat fenomena yang unik dalam nominalisasi SH itu, yakni "menyembunyikan" ide dasar yang lebih penting ke dalam penggunaan nominalisasi agen dan mengedepankan ide yang kurang penting ke dalam "proses" klausa. Pendayagunaan nominalisasi seperti yang dilakukan SH di atas banyak dilakukan oleh elite-elite politik lainnya, baik dari pihak pemerintah yang berkuasa maupun dari kelompok oposisi.

Apa pun bentuk nominalisasi yang dipilih, terdapat satu fenomena yang menarik yakni keberadaan nominalisasi sebagai alat untuk mencapai tujuan ideologis-politis tertentu. Pilihan nominalisasi bukan semata- mata alasan lingual semata, tetapi sarana yang sangat strategis untuk keperluan menyembunyikan "agenda tertentu" dalam mencapai tujuan ideologis tertentu.

Pilihan Kalimat Aktif dan Pasif. Secara umum, teks-teks politik Indonesia era pasca-Orde Baru lebih didominasi oleh penggunaan kalimat aktif dibandingkan dengan kalimat pasif. Dengan demikian, jika fenomena ini diacukan kepada pendapat Orwell (1946) yang menganjurkan agar elite politik lebih menggunakan kalimat aktif dibandingkan pasif, realitas pendayagunaan bahasa politik Indonesia relatif ideal seperti anjuran Orwell di atas.

Meskipun begitu, elite politik Indonesia juga mendayagunakan secara intensif bentuk kalimat pasif untuk berbagai aktivitas politiknya. Terdapat tiga bentuk pasif, yakni (1) pasif "di-", (2) pasif dengan pengedepanan objek, dan (3) pasif "ter-". Hasil penelitian menunjukkan bahwa bentuk pasif "di-" lebih banyak didayagunakan oleh elite politik Indonesia untuk berbagai aktivitas politiknya, diikuti oleh pasif dengan verba "ter" dan pasif persona. Perhatikan contoh (2) berikut

(2) SH: (1) Memang, dari awal diakui di sana sini ada kelemahan. (2) Sebagai sebuah lembaga baru, dan di dalamnya juga terdiri atas orang-orang yang berbeda, pemerintah berusaha mencermati dengan dekat sekali. (3) Pendekatan ini dilakukan dengan landasan pada keharmonisan hubungan antara pemerintah anggota KPU lainnya.

Pada kutipan (2) tersebut kalimat pertama dibangun dari ragam pasif, kalimat kedua dibangun dari ragam aktif, kalimat ketiga dibangun dari ragam pasif. Pada kalimat pertama, ketidakhadiran agen menimbulkan satu pertanyaan penting, yakni "siapa yang mengakui?". Jika yang berbicara adalah SH selaku Menteri Dalam Negeri, jawaban terhadap pertanyaan itu adalah "pemerintah". Dalam kasus itu SH tidak mengedepankan agen pemerintah yang menjadi "penanggung jawab 
KPU dengan mengakui kelemahan-kelemahan kinerjanya", tetapi lebih menyembunyikan kehadiran agen dengan mendayagunakan pasif tanpa kehadiran agen, peranan "agen yang bertanggung jawab" dinetralkan. Pada kalimat kedua, SH mendayagunakan bentuk kalimat aktif dengan mengedepankan kehadiran agen dalam kalimat. Ketidakhadiran goal dalam kalimat itu tidak menimbulkan pertanyaan karena secara eksplisit sudah hadir dalam keterangan yang diekspresikan lebih dahulu daripada klausa intinya, yakni agen dan proses. Pada kalimat ketiga, SH mendayagunakan bentuk kalimat pasif dengan ketidakhadiran agen. Jika diperhatikan, ketidakhadiran agen pada kalimat ketiga ini berbeda dengan kalimat pertama. Pada kalimat ketiga, ketidakhadiran agen tidak menimbulkan permasalahan yang signifikan terhadap penghilangan agen. Modelmodel pendayagunaan bentuk pasif seperti pada kutipan (2) di atas banyak muncul dalam teks-teks lain yang dihasilkan oleh sejumlah elite politik Indonesia era pasca-Orde Baru. Kalimat dengan susunan "agen+proses kejadian+keterangan" itu mengandung makna yang impersonal dan formal sehingga menciptakan jarak dan suasana kaku.

Yang harus dijelaskan adalah persoalan urutan intensitas pilihan bentuk pasif yang diawali bentuk "di- ", "ter- ", dan yang terakhir "pasif persona". Mengapa bentuk "di- " dan "ter-" lebih mendominasi teks- teks politik pada era pasca-Orde Baru ini? Mengapa bentuk "pasif persona" sedikit didayagunakan? Dua pertanyaan ini mengarahkan kita kepada pemahaman bahwa elite politik Indonesia lebih menyukai memilih dan mendayagunakan bentuk pasif yang mengandung makna impersonal, kaku, serta formal dan kurang menyukai bentuk pasif yang mengandung makna personal, lentur, dan informal.

Pilihan Kalimat Positif dan Negatif. Pertanyaan yang layak dimunculkan adalah "mengapa elite politik Indonesia pada era pasca-Orde Baru lebih memilih kalimat negatif jika nilai pengalaman itu dapat diungkapkan dalam kalimat positif'. Dalam teks-teks politik Indonesia, kalimat negatif yang dipilih menggunakan tiga bentuk kosakata pemarkah negatif, yakni "tidak", "bukan", dan "jangan". Bentuk pasif ada yang menjalankan (1) fungsi "negatif yang sebenarnya", (2) fungsi "manipulatif", dan (3) fungsi "ideologis". Bentuk negatif yang pertama digunakan apabila bentuk negatifnya memang lebih tepat mengkodekan realitas daripada bentuk positifnya. Istilah pasif "tidak berkoalisi" dalam kalimat PAN tidak berkoalisi dengan siapa-siapa, misalnya, tentu saja lebih informatif daripada bentuk positifnya"berjuang sendirian" dalam kalimat PAN berjuang sendirian.

Bentuk negasi yang menjalankan fungsi “manipulatif", bahkan "ideologis" dapat diperhatikan pada contoh (3) berikut.

(3): MDI: Kalau ingin melakukan komunikasi secara jujur, kelebihan semacam itu mestinya diungkapkan juga. Saya setuju bila pers mengungkap beberapa ketidakmampuan dan ketidakberhasilan Pak Habibie. Tapi agar informasi itu adil dan jujur, kelebihan-kelebihan yang dimiliki beliau juga harus diberitakan secara imbang. Kesalahan satu bagi beliau seakan begitu saja menghilangkan beberapa kelebihan yang dimiliki Pak Habibie. Itu namanya tidak adil.

Kutipan (3) dicuplik dari teks hasil wawancara wartawan dengan Marwah Daud Ibrahim. Dalam kutipan (3) terdapat tiga bentuk pasif, yakni ketidakmampuan, ketidakberhasilan, dan tidak adil Kata negatif "ketidakmampuan" memiliki bentuk positif "kebodohan" dan "kelemahan", kata "ketidakberhasilan" memiliki bentuk positif "kegagalan", serta "tidak adil" memiliki bentuk positif "aniaya". Dalam penggunaannya, katakata negatif itu memiliki makna yang lebih halus dan lebih tidak langsung. Kata-kata negatif itu memiliki nuansa eufemisme. Secara normatif, dalam komunikasi politik yang lebih jujur dan terbuka, pilihan bentuk positiflah yang lebih sesuai. Dengan demikian, pilihan bentuk negatif memiliki signifikansi ideologis tertentu. Pilihan bentuk negatif dalam kutipan 
(3) menjalankan fungsi "manipulatif", dan bahkan "ideologis".

Dari paparan di atas dapat diperoleh pemahaman bahwa bentuk negasi yang dipilih dan didayagunakan oleh elite politik menjalankan beberapa peran. Terdapat bentuk negasi yang menjalankan peran sebagai "negasi yang sebenarnya" karena bentuk positifnya tidak cocok untuk digunakan atau bentuk positifnya terlalu luas. Selain itu, terdapat juga bentuk negasi yang menjalankan peran sebagai "manipulatif" karena penggunaannya dipaksakan sementara bentuk positifnya tersedia. Terdapat juga bentuk negasi yang menjalankan peran sebagai "ideologis" karena bentuk negasi itu dipaksakan penggunaannya dan diperjuangkan melalui berbagai aktivitas politik penghasil teks.

\section{b. Nilai Relasi Gramatika dalam Wacana Politik}

Pilihan Modus Kalimat. Secara umum, kalimat deklaratif mendominasi teksteks politik Indonesia. Hal ini mengandung makna bahwa elite politik Indonesia sebagai penghasil teks berperan sebagai pemberi informasi, sementara itu masyarakat Indonesia sebagai penerima informasi. Hasil penelitian juga menunjukkan bahwa bahwa pilihan terhadap kalimat deklaratif sebagai sarana pembentuk teks politik memiliki dimensi yang cukup menarik. Sebuah modus kalimat deklaratif tidaklah selalu berkorelasi dengan posisi subjek tertentu. Sebuah kalimat deklaratif dapat juga memberi kan informasi berbagai posisi yang diemban subjek tertentu. Kalimat interogatif juga cukup banyak didayagunakan dalam teks-teks politik. Perhatikan contoh (4) berikut.

(4): HM: Lho, kan jelas siapa orangorang yang berada di PDI Perjuangan. Itu seperti Jacob Tobing yang mantan ketua Bapilu Golkar 1997, Theo Syafei, dan lain lain, masak begitu mudahnya loncat ke PDI Perjuangan. Bukankah mereka orang yang dulu dipakai Orde Baru? Apakah PDI Perjuangan tidak khawatir kebiasaan

\section{Orde Baru akan ditularkan kepada mereka?}

Kutipan (4) di atas adalah cuplikan dari wawancara HM dengan beberapa wartawan. Dalam kutipan itu terdapat dua kalimat interogatif. Kalimat interogatif pertama tidak menempatkan posisi tertentu pada penutur maupun mitra tutur. Jika dalam kalimat interogatif yang biasa menempatkan penutur sebagai subjek yang meminta informasi dan mitra tutur sebagai penyedia informasi, analisis terhadap kalimat tersebut akan menemui kendala. Kalimat itu yang secara sintaksis adalah interogatif, secara semantis bukanlah pertanyaan, tetapi lebih berupa proposisi yang seharga dengan kalimat deklaratif. Kalimat tersebut secara pragmatik bukanlah bertanya, tetapi berupa pernyataan. Kalimat tersebut menjalankan fungsi sebagai tindak representatif. Penutur "menyatakan" sesuatu kepada orang lain, yakni "para pemikir PDI Perjuangan sekarang berasal dari tokoh-tokoh PG yang pernah lama dipakai oleh Pemerintah Orde Baru".

Dalam kalimat interogatif kedua, penutur bukan sebagai subjek yang meminta informasi dan mitra tutur sebagai penyedia informasi, tetapi penutur adalah penyedia informasi dan mitra tutur adalah penerima informasi. Kalimat interogatif kedua tersebut secara sintaksis adalah kalimat interogatif. Dari kacamata semantik, kalimat tersebut bukanlah pertanyaan, tetapi lebih berupa proposisi. Dari kacamata pragmatik, kalimat tersebut bukanlah aktivitas bertanya, tetapi lebih berupa pernyataan.

Dari keseluruhan pendayagunaan modus kalimat yang ada, kalimat deklaratif dengan makna "menyatakan" menduduki tempat pertama dalam jumlah. Kalimat interogatif yang didayagunakan pun secara semantis juga lebih banyak berkaitan dengan makna "menyatakan" itu. Hal ini berarti bahwa posisi elite politik Indonesia dalam teks- teks politik lebih banyak mengambil posisi sebagai "pemberi informasi", sementara itu masyarakat Indonesia lebih banyak sebagai "penerima 
informasi”.

Pilihan Modalitas Relasional. Modalitas relasional banyak didayagunakan dalam teks-teks politik. Beberapa makna yang muncul berkenaan dengan pilihan modalitas relasional ini, antara lain: 'keharusan', 'keteramalan', 'kemampuan', 'kepastian', 'kemungkinan', 'keinginan', 'harapan', 'pembiaran', dan 'perintah'. Hasil penelitian menunjukkan bahwa modalitas yang menyatakan 'keharusan' banyak digunakan elite politik. Modalitas ditandai oleh penggunaan kata-kata, antara lain "harus", "mesti", "wajib", dan "(se)harusnya". Simak contoh (5) berikut.

(5): MD: Ya, kalau yang kecil-kecil ini ditumpuk-tumpuk, kan menjadi besar juga. Dan tentu, sokongan kepadanya akan bertambah banyak, khususnya dari kaum reformis. Tetapi, bagaimana pun dia harus mencari formula yang lebih tepat agar hasilnya cukup efektif, khususnya soal pengusutan Pak Harto.

Kutipan (5) dicuplik dari teks hasil wawancara wartawan dengan $\mathrm{MD}$, salah seorang elite Partai Golkar. Dalam kutipan tersebut MD menggunakan kata "harus" untuk menyatakan bahwa apa yang dikemukakannya adalah sesuatu yang amat penting sehingga "wajib" dilakukan oleh Habibie. Kata "harus" dalam kalimat itu mengandung implikasi imperatif bagi sasaran yang dituju. Satu rumusan penting berkaitan dengan contoh (5) adalah masalah penonjolan autoritas oleh penutur terhadap pihak lain agar melakukan suatu tindakan tertentu yang tidak dapat ditawar-tawar. Elite politik ingin menunjukkan bahwa posisi yang sedang didudukinya dan aktor yang sedang diperankannya itu memiliki kekuatan imperatif dan direktif untuk menggerakkan orang lain dalam suatu komunikasi politik yang sering bersifat timpang.

Modalitas yang selanjutnya banyak digunakan adalah modalitas yang bermakna 'keteramalan'. Modalitas ini ditandai oleh penggunaan kata-kata, antara lain "akan", "saya kira", "saya rasa", "saya pikir", "agaknya", "kelihatannya", "diduga", "dikira”, "pada hemat saya", dan "menurut pendapat saya". Perhatikan contoh (6) berikut.

(6) SBP: $N \quad$ [...] Untuk mewujudkan Indonesia, siapa pun yang menjadi presiden nanti jika tidak mewujudkan Indonesia baru saya kira akan gagal untuk mewujudkan ke makmuran yang abadi bagi masyarakat Indonesia.

Kutipan (6) dicuplik dari teks pembukaan debat calon presiden yang disampaikan oleh SBP. Dalam kutipan (6) SBP mendayagunakan dua modal yang menyatakan 'keteramalan' sekaligus, yakni "saya kira" dan "akan". Dua modal tersebut dipergunakan untuk memberikan "ramalan" atau "prediksi" bagi siapa saja yang nantinya menduduki presiden keempat RI. Dalam prediksi SBP, Indonesia baru adalah syarat mutlak keberhasilan seorang presiden di Indonesia.

Dengan demikian, diperoleh pemahaman bahwa sejumlah elite politik menempatkan dirinya sebagai "pemrediksi" atau "peramal" tentang pelbagai hal yang berkaitan dengan sosial ekonomi, sosial politik, dan sosial budaya. Ketepatan akan prediksi akan menambah nilai elite yang bersangkutan untuk mencapai tujuan politisnya melalui pelbagai aktivitas politisnya itu.

Pilihan Strategi Kehadiran Diri. Pilihan strategi kehadiran diri berimplikasi terhadap jarak sosial yang tercipta antara penutur dan petururnya. Beberapa strategi kehadiran diri yang dipilih oleh elite politik dalam komunikasi adalah (1) penggunaan pronomina persona jamak kita, dan (2) penggunaan pronomina jamak kami, (3) penggunaan pronomina persona tunggal saya, dan (4) penggunaan nomina tertentu sebagai pengganti pronomina.

Hasil penelitian menunjukkan bahwa pronomina persona "kita" cukup mendominasi dalam sejumlah pilihan strategi yang ada. Hal itu dapat diperhatikan pada kutipan (7) berikut.

(7): HM: Bukan soal menang atau kalah. Karena pada prinsipnya yang 
menuntut itu bukan kita sebagai partai. Tetapi, rakyat Indonesia telah menegur PDI Perjuangan, mengapa PDI Perjuangan mau dijadikan tunggangan kelompok tertentu [...]

Kutipan (7) dicuplik dari teks hasil wawancara wartawan dengan HM, tokoh Partai Bulan Bintang. Dalam (7) penghasil teks menghadirkan dirinya dengan pronomina persona "kita" Pronomina "kita" adalah pronomina persona jamak yang bersifat inklusif. Dalam "kita" terkandung kehadiran "saya" dan "Anda". Terdapat fenomena yang menarik dalam kutipan tersebut, yakni konstruksi "kita sebagai partai". Secara normatif, penghasil teks seharusnya hadir dengan menggunakan pronomina persona "kami" sebagai media menghadirkan dirinya karena memang tuntutan yang paling keras berkaitan dengan dominannya caleg nonmuslim PDI. Dalam konteks ini, penutur "melibatkan" dan "menyeret" mitra tutur ke dalam persoalan yang mungkin saja hanya dipersoalkan oleh penutur. Penutur memandang masalah tersebut bukan semata-mata masalah "saya" yang bersifat eksklusif, tetapi "kita" yang bersifat inklusif. Perhatikan contoh (8) berikut.

(8): SBY: Asumsi yang dibangun oleh sebagian masyarakat-saya tidak yakin kalau asumsi itu pandangan seluruh masyarakat Indonesia - saya amat yakin itu buah pikiran kelompok masyarakat. ABRI sangat tidak setuju dengan asumsi-asumsi, itu dan memang bukan itu tujuan ABRI untuk mengadakan dialog. Saya tidak sependapat dengan pandangan "coba kita lihat, mampu tidak pemerintah menyelesaikan krisis ini dalam jangka waktu sekian bulan”. Bagi ABRI, apa memang hanya tanggung jawab pemerintah menyelesaikan krisis. Tanggung jawab kita.

Kutipan (8) dicuplik dari teks hasil wawancara wartawan dengan SBY. Dalam kutipan tersebut penghasil teks hadir dengan beberapa strategi, yakni pronomina persona "saya", "kita", dan "nomina ABRI". Siapakah "saya" dalam kutipan tersebut? Pronomina "saya" dapat mengacu kepada "SBY sebagai orang pertama tunggal" yang lepas dari baju institusinya. Pronomina "saya" juga dapat mengacu kepada "SBY sebagai orang pertama tunggal yang menggunakan baju institusi". Dalam konteks institusi TNI/ABRI, sejumlah agen yang hadir akan menyuarakan "suara kolektif" sesuai dengan garis kepemimpinan TNI/ABRI yang bersifat lini. Dengan demikian, pronomina "saya" dapat mendua makna, yakni saya sebagai orang pertama tunggal dan saya sebagai institusi TNI/ABRI. Hanya saja, dalam konteks tersebut, penggunaan saya mengandung nuansa makna "penonjolan kekuasaan". Penggunaan "kita" dalam kedua kalimat di atas mengandung makna ideologis-politis, yakni melibatkan mitra tutur ke dalam persoalan penutur meskipun mitra tutur itu belum tentu menghadapi persoalan yang sama. Dua fenomena itu mengandung proses pelibatan partisipan "orang kedua" ke "orang pertama jamak" dalam sebuah komunikasi politik.

\section{c. Nilai Ekspresif Gramatika dalam Wacana Politik}

Hasil penelitian menunjukkan bahwa modalitas yang menyatakan 'keharusan' mendominasi bahasa elite politik, diikuti modalitas keteramalan, modalitas kepastian, dan modalitas harapan. Perhatikan contoh (9) berikut.

(9): AWM: Sebelum saya menjelaskan hal tersebut perlu ditekankan di sini bahwa ABRI dalam gerakan reformasi selalu mendukung reformasi yang mengarah ke kondisi yang lebih baik. Sekarang ini tampaknya belum ada kesepakatan bersamasoal itu. Jangan lupa, reformasi harus dijalankan sesuai dengan UUD 1945, Pancasila, memperhatikan stabilitas nasional, persatuan dan kesatuan bangsa, serta dilakukan secara kesinambungan. 
Kutipan (9) dicuplik dari teks hasil wawancara wartawan dengan AWM. Dalam kutipan itu penghasil teks menggunakan modalitas yang menyatakan makna 'keharusan'. Dengan modal "harus" tersebut institusi TNI/ABRI ingin menunjukkan autoritasnya dalam memandang kebenaran, yakni reformasi yang baik adalah reformasi yang dijalankan sesuai dengan UUD 1945 dan Pancasila, memperhatikan stabilitas nasional, persatuan, dan kesatuan bangsa, dilakukan secara kesinambungan.

\section{d. Perspektivitas Pilihan Gramatika dalam Wacana Politik}

Mengambil pandangan Fairclough (1989) dua pertanyaan diajukan. Pertanyaan pertama adalah "proses institusional apa yang terjadi dalam teks politik dan bagaimana proses itu secara ideologis 'ditentukan' oleh relasirelasi kuasa dan pertarungan kuasa serta determinatif dari relasi-relasi kuasa dan pertarungan kuasa pada tataran instisusi dan sosial". Pertanyaan kedua adalah "proses sosiokultural apa yang terjadi dan bagaimana proses itu secara ideologis 'ditentukan' oleh relasi-relasi kuasa dan pertarungan kuasa serta determinatif dari relasi-relasi kuasa dan pertarungan kuasa".

Proses Institusional. Terdapat sebuah proses institusional yang cukup kompleks dalam wacana politik Indonesia. Proses itu berupa "pertarungan" lintas institusi yang akhirnya bermuara ke dalam wacana politik. Pilihan dan pemaknaan terhadap penggunaan bentuk-bentuk gramatika tertentu amatlah dipengaruhi oleh asumsi-asumsi yang dibangun elite politik pada tataran institusi.

Pertama, dalam pilihan sistem ketransitifan, misalnya, amatlah ditentukan oleh institusi yang melingkupi dan mendeterminasi elite politik. Dalam konteks ini terdapat suatu "pertarungan pilihan ketransitifan" yang amat kontradiktif antara institusi pemerintah yang dianggap resmi dan institusi nonpemerintah yang mengklaim dirinya sebagai kelompok prodemokrasi. Institusi pemerintah sangat menonjolkan peran "proses" klausa sebagai pembawa ideologi institusi. Verba-verba yang menduduki proses, yakni "ingin menyelamatkan", "tidak bisa menjalankan", "tidak pernah akan mendorong dan mendukung", dan "selalu mendukung" cukup ditonjolkan dalam pilihan klausa. Verbaverba yang mendatangkan makna 'mempertahankan apa yang sudah ada' begitu diperjuangkan melalui berbagai proses naturalisasi agar menjadi bagian dari kesadaran masyarakat Indonesia. Sebaliknya, institusi nonpemerintah sangat menonjolkan peran "goal" dalam klausa atas ungkapan-ungkapan politik yang lebih didominasi ragam pasif. Nomina-nomina seperti "disintegrasi", "Orde Baru", "Orde Baru yang ingin menang", dan "mereka (Orde Baru)" cukup ditonjolkan dalam pilihan klausa. Di luar kedua institusi di atas, institusi yang memiliki sejarah masa lalu dengan Partai Masyumi yang pernah jaya pada pada pemerintahan Orde Lama dan sudah dibubarkan oleh Soekarno menonjolkan peran "keterangan" klausa sebagai pembawa ideologi konstitusi. Pengisi keterangan, seperti "di atas sistem yang kuat", "pada satu orang seperti yang terjadi di 53 tahun belakangan ini", dan "bukan tunduk pada orang menempatkan" posisi ideologi penghasil teksnya, yakni "pementingan sistem yang mantap, bukan pada figur".

Kedua, dalam pilihan nominalisasi, antara institusi pemerintah yang berkuasa dengan institusi kelompok prodemokrasi tidak terlalu terjadi pertarungan antarinstitusi itu. Terdapat kesamaan dalam pilihan nominalisasi itu, yakni adanya kecenderungan menyembunyikan ide dasar yang lebih penting ke dalam penggunaan nominalisasi agen dan mengedepankan ide yang kurang penting ke dalam bagian yang menduduki "proses" dalam klausa yang menggunakan pola urutan "agen+proses+goal" atau "agen+proses".

Ketiga, dalam pilihan kalimat pasif, antara institusi pemerintah yang berkuasa dengan institusi kelompok prodemokrasi tidak terlalu terjadi pertarungan antarinstitusi itu. Terdapat kesamaan dalam pilihan kalimat pasif, yakni terdapatnya kecenderungan memilih 
bentuk pasif yang berverba "di- ", kemudian diikuti oleh pasif dengan verba "ter- ", dan yang terakhir pasif dengan pengedepanan objek atau pasif persona. Dengan demikian, elite politik Indonesia memiliki kecenderungan menggunakan pasif tanpa kehadiran agen. Pilihan bentuk ini mengakibatkan persoalan "kausalitas" dan "peragenan" yang tidak jelas. Ketidakhadiran agen dalam pasif "di-" menimbulkan kesan bahwa ekspresi tersebut lebih bersifat impersonal, berjarak, kaku, dan formal.

Keempat, dalam pilihan kalimat positif dan negatif, antara institusi pemerintah yang berkuasa dengan institusi kelompok prodemokrasi tidak terlalu terjadi pertarungan antarinstitusi itu. Terdapat kesamaan dalam pilihan negasi, yakni kecenderungan memilih bentuk negatif yang menjalankan fungsi "manipulatif" dan "ideologis". Elite politik Indonesia cenderung menggunakan bentuk negatif meskipun terdapat bentuk positifnya yang lebih bersifat langsung dalam melaporkan realitas. Fenomena tidak terjadinya pertarungan antarinstitusi juga terjadi pada pilihan pilihan modus kalimat, strategi kehadiran diri, dan modalitas. Terdapat kecenderungan fenomena yang sama dalam pilihan masing-masing bentuk gramatika tersebut.

Proses Sosiokultural. Terdapat sebuah proses sosiokultural yang cukup kompleks dalam wacana politik Indonesia pada era pascaOrde Baru. Proses itu berupa "pertarungan" lintas sistem sosiobudaya "lama" dan sistem sosiobudaya "baru". Sistem budaya lama Indonesia yang didominasi oleh sistem budaya Jawa mendapat tantangan sistem budaya yang lebih global yang secara normatif tidak sesuai dengan budaya lama.

Memanfaatkan pandangan Alisjahbana (1982:1986), proses sosiokultural yang terjadi dalam wacana politik Indonesia adalah "pertarungan" antara sistem budaya "ekspresif" dan "progresif", termasuk di dalamnya sistem budaya yang berdasarkan "agama". Masih berkuasanya alam pikiran lama yang tercermin dalam pilihan sistem ketransitifan yang dilakukan oleh sejumlah elite politik Indonesia.
Sistem budaya lama yang dipersonifikasikan pada diri institusi pemerintah yang berkuasa mendapat tantangan dari sistem budaya baru yang dipersonifikasikan pada diri institusi nonpemerintah. Sistem budaya lama yang bermuara pada ideologi 'mempertahankan apa yang sudah ada' mendapat tantangan dari sistem budaya baru yang bermuara pada 'ideologi pembaharuan di segala bidang kehidupan'.

Pada tataran gramatika ini, pertarungan antara "sistem budaya lama" dengan "sistem budaya baru" mendapat pencerahan dari jalan tengah, yakni dari sistem budaya Islam. Dalam pandangan sistem budaya ini, ajaran agama haruslah dijadikan sumber moral dalam menjalankan aturan pemerintahan. Oleh karena itu, yang terpenting dalam melaksanakan roda pemerintahan Indonesia adalah perlunya diperjuangkan ideologi yang dapat memperbaiki Indonesia, yakni pementingan sistem yang mantap, bukan figur tokoh.

\section{PENUTUP}

Berdasarkan kajian di atas dapat disimpulkan hal-hal sebagai berikut.

1. Terkait dengan nilai pengalaman gramatika, elite politik menggunakan ketransitifan yang bermakna material, nominalisasi agen, pilihan pasif, dan pilihan negatif untuk menunjukkan kekuasaan dan menyembunyikan posisi ideologisnya.

2. Terkait dengan nilai relasi gramatika, elite politik (a) lebih memerankan dirinya sebagai pemberi informasi dan menempatkan masyarakat awam sebagai penerima informasi, (b) menunjukkan autoritasnya di hadapan elite politik lainnya dan masyarakat Indonesia secara keseluruhan, (c) menunjukkan kekuasaan melalui pilihan pronomina persona "kita" dan "saya".

3. Terkait dengan nilai ekspresif, elite politik banyak mendayagunakan modalitas yang menyatakan autoritas penutur terhadap kebenaran atau kemungkinan representasi realitas. 
4. Dalam memilih bentuk-bentuk gramatika tertentu, terdapat dua proses sosial yang terjadi, yakni (1) proses institusional, yakni pertarungan lintas institusi, dan (2) proses sosiokultural, yakni pertarungan nilai sosiobudaya lama dan sosiobudaya baru.

\section{DAFTAR PUSTAKA}

Alisjahbana, S.T. 1982. Sejarah Kebudayaan Indonesia Dlihat dari Segi Nilai-Nilai. Jakarta: Dian Rakyat.

Alwi, H. 1992. Modalitas Bahasa Indonesia. Yogyakarta: Penerbit Kanisius.

Birch, D. 1996. Critical Linguistics as Cultural Process. Dalam James, J.E. (Ed.), The Language-Culture Connection (halaman 64-85). Singapore: SEAMEO Regional Language Centre.

Bosmajian, H. 1986. Dehumanizing People and Euphemizing War. Dalam Goshgarian, G. (Ed.), Exploring Language (halaman 92-99). Fourth Edition. Boston: Little, Brown, and Company.

Cross, D.W. 1986. Politics: The Art of Bamboozling. Dalam Goshgarian, G. $(E d$.$) , Exploring Language (halaman$ 73-91). Fourth Edition. Boston: Little, Brown, and Company.

Crystal, David. 1991. A Dictionary of Linguistics and Phonetics. Oxford: Basil Blackwell Ltd.

Fairclough, N. 1989. Language and Power. New York: Longman Group UK Limited.

Fairclough, N. 1995. Critical Discourse Analysis: The Critical Study of Language. Harlow-Essex: Longman Group Limited.
Fowler, R. 1986. Linguistic Criticism. Oxford: Oxford University Press.

Geertz, C. 1991. Tafsir Kebudayaan. Yogyakarta: Penerbit Kanisius.

Halliday, M.A.K. 1985/1994. An Introduction to Functional Grammar. London: Edward Arnold Publishers Ltd.

Orwell, G. 1986. Politics and the English Language. Dalam Goshgarian, G. (Ed.), Exploring Language (halaman 60-72). Fourth Edition. Boston: Little, Brown, and Company.

Mueller, C. 1980. The Maintenance of the Status Quo. Dalam Pugh, A.K., Lee, V.J., \& Swann, J. (Eds.), Language and Language Use (halaman 105-124). London: Heinemann Educational Books, Ltd.

Richards, J.C., Platt, J., \& Platt, H. 1992. Longman Dictionary of Language Teaching and Applied Linguistics. Second Edition. Harlow-Essex: Longman UK Limited.

Safire, W. 1986. Acronyms Sought. Dalam Goshgarian, G. (Ed.), Exploring Language (halaman 107-111). Fourth Edition. Boston: Little, Brown, and Company.

Samsuri. 1985. Tata Kalimat Bahasa Indonesia. Jakarta: PT Sastra Hudaya.

van Dijk, T. 1985. Introduction: The Role of Discourse Analysis in Society. Dalam van Dijk, T. (Ed.), Handbook of Discourse Analysis Volume 4: Discourse Analysis in Society (halaman 1-8). London: Academic Press. 